\title{
Predictive baseline criteria of primary therapeutic failure in chronic hepatitis $\mathrm{C}$ genotype 1
}

\author{
F. Cuenca ${ }^{1}$, C. Fernández², M. J. Devesa ${ }^{1}$, G. López-Alonso ${ }^{1}$ J. Mayol ${ }^{3}$, A. Suárez $^{4}$, L. Ortega $^{5}$, \\ M. Díaz-Rubio ${ }^{1}$ and J. M. Ladero ${ }^{1}$ \\ Departments of ${ }^{1}$ Gastroenterology, ${ }^{2}$ Preventive Medicine, ${ }^{3}$ Surgery, ${ }^{4}$ Clinical Microbiology, and ${ }^{5}$ Pathology. Hospital \\ Clínico San Carlos. Universidad Complutense de Madrid. Spain
}

\begin{abstract}
Background and aims: more than half of patients with genotype 1 chronic hepatitis $\mathrm{C}(\mathrm{CHC})$ do not achieve a sustained viral response (SVR) to current antiviral therapy due to primary non-response, relapse or intolerance. Factors related to each of these unfavorable outcomes are different and the last two may be partially prevented. Our aim was to identify basal criteria to predict the risk of primary failure.

Patients and methods: we included 251 consecutive patients (152 males) from a single centre, infected with HCV genotype 1 and not previously treated. SVR was achieved in 141 patients and primary failure in 110 .

Results: high vs. low viral load $(>400,000 \mathrm{IU} / \mathrm{mL}$, OR $=$ 6.17; 95\% CI: 2.50-15.23), high serum GGT (> $60 \mathrm{IU} / \mathrm{mL}$, OR $=4.25 ; 95 \% \mathrm{CI}: 2.49-7.24)$, low serum cholesterol $(<178$ $\mathrm{mg} / \mathrm{dL}, \mathrm{OR}=2.93 ; 95 \% \mathrm{CI}: 1.75-4.92$ ) and older age (> $47 \mathrm{yrs}$, $\mathrm{OR}=1.79 ; 95 \% \mathrm{CI}: 1.08-2.96)$ were associated to the risk of primary failure in the lineal logistic regression analysis. From the 58 patients carrying all the first three negative criteria, 46 (79.3\%) were primary non-responders.

Conclusions: the negative basal profile identified in this study is based on easily available data and provides information about the risk of primary therapeutic failure, and may help to decide whether antiviral therapy should be offered to a single patient.
\end{abstract}

Key words: Hepatitis C virus. Predictive factors. Pegylated interferon. Ribavirin. Thyroid hormones.

Cuenca F, Fernández C, Devesa MJ, López-Alonso G, Mayol J, Suárez A, Ortega L, Díaz-Rubio M, Ladero JM. Predictive baseline criteria of primary therapeutic failure in chronic hepatitis C genotype 1. Rev Esp Enferm Dig 2010; 102: 234-238.

Received: 21-10-09.

Accepted: 23-12-09.

Correspondence: José M. Ladero. Liver Unit. Hospital Clínico San Carlos. C/ Martín Lagos, s/n. 28040 Madrid. e-mail: jladero.hcsc@salud.madrid.org

\section{INTRODUCTION}

Current therapy for genotype 1 chronic hepatitis $\mathrm{C}$ combines weekly doses of pegylated interferon $(\alpha 2 \mathrm{a}$ or $\alpha 2 b)$ and daily oral ribavirin at weight-adjusted doses during 48 weeks. This therapy is considered successful if viral RNA is undetectable in peripheral blood after six months of the end of therapy with a high sensitivity assay. Less than $50 \%$ of patients obtain this "sustained viral response" (SVR) in most of the published pivotal clinical trials (1-3) and in many reports on real clinical practice (4-7). The remaining patients may experience: a) primary therapeutic failure, currently defined with the universally accepted "12 (2) and 24 (1) week stopping rules"; b) viral relapse after clearing viral RNA before the week 24 of therapy; and c) severe adverse events causing premature interruption of therapy (intolerance).

Although adverse events are frequent during treatment, most patients overcome them with specific supportive measures. Intolerance is largely unpredictable and causes premature interruption of therapy in less than $10 \%$ of treated patients. Viral relapse is related to a delayed response to therapy. Patients with a drop $>2 \log 10$ but still detectable viral load at week 12 are firm candidates to suffer from viral relapse if they achieve undetectable viral load at week 24 (8), and the current strategy is to prolong therapy until 72 weeks, in an attempt to improve the rate of SVR (9-11).

Most of published studies on this issue aimed at identifying the basal factors that influence the rate of therapeutic success compared patients reaching SVR with a group composed of primary non-responder, relapser and nontolerant patients. As these categories represent different types of failure and, in some cases (relapsers and patients with severe adverse events), strategies have been developed to improve the results of therapy, it seems that a change in perspective may be more informative about the risk of a patient to experience primary therapeutic failure, 
the only scenario for which we do not have an alternative strategy.

Therefore, we designed the present study with the aim to elucidate whether there are clinical, biochemical and viral factors associated to the risk of primary therapeutic failure by comparing a group of patients with primary failure with a group of patients who reached SVR.

\section{PATIENTS AND METHODS}

This is a retrospective study based on the review of the clinical records of all the chronic hepatitis $\mathrm{C}$ patients treated at our Liver Unit with pegylated interferon and ribavirin since this combined therapy was available at our center (September 2001). All patients were treated in accordance with Spanish (11) and international $(12,13)$ guidelines. A total of 633 patients had been treated and reached one of the four end-points previously defined. Five hundred and thirty of these patients had never been previously treated with interferon and/or ribavirin (i.e., they were naïve for therapy), and 376 were infected with genotype 1.

For this study, we selected for further analysis only the genotype 1 naïve patients, who obtained sustained viral response six months after the end of therapy or experienced primary failure at weeks 12 or 24 of therapy.

The diagnosis of chronic hepatitis $\mathrm{C}$ was based on clinical evaluation together with results of biochemical and virological tests. All patients were positive for antiHCV since at least 6 months before the beginning of therapy, and HCV-RNA was detectable in blood samples of all individuals when treatment was started. Standard serological tests were used to exclude individuals with active infection with hepatitis B or human immunodeficiency viruses.

Quantitative analysis of HCV-RNA was performed with the Cobas Amplicor HCV Monitor version 2.0 (Roche Molecular Diagnostic). The detection range was $600 \mathrm{IU} / \mathrm{mL}$ to $8.5 \times 10^{5} \mathrm{IU} / \mathrm{mL}$. Starting from July 2005 , viral RNA was extracted automatically using Cobas AmpliPrep, and the viral load was detected using Real-Time polymerase chain reaction (PCR) using Cobas TaqMan (Roche Diagnostics) which has a detection range of between $10 \mathrm{IU} / \mathrm{mL}$ and $2 \times 10^{8} \mathrm{IU} / \mathrm{mL}$ (14).

$\mathrm{HCV}$ genotypes were determined by a reverse hybridization assay (INNO-LiPA; Innogenetics). The genotypes are assigned on the basis of sequence variations in the 5'untranslated region of HCV following gene amplification using reverse transcription polymerase chain reaction (RT-PCR).

Results of liver biopsy were also collected, when available; the stage of fibrosis was established according with Knodell et al. (15) and classified as null-low or advanced fibrosis (categories 0-1 and 3-4, respectively, of the item 4 of the Knodell scoring system).

\section{Statistical analysis}

With the objective of establishing which parameters were significantly different between the two groups of patients, a comparison was made for age, gender, body mass index [body weight in $\mathrm{kg} /(\text { height in } \mathrm{m})^{2}$ ], hemoglobin, leukocyte, neutrophil and platelet counts, AST, ALT, AST/ALT ratio, GGT, alkaline phosphatase, serum cholesterol, viral subtype (1b vs. 1 non-b), viral load ( $\leq$ 400,000 IU vs. > 400,000 IU), type of pegylated interferon $(\alpha 2 \mathrm{~b} v s . \alpha 2 \mathrm{a})$, dose of ribavirin adjusted to BMI and, when available, histological stage of fibrosis. Continuous variables were compared with the Student' t test or the Mann-Whitney $U$ test, each when adequate, depending on their Gaussian distribution. A p value $<0.05$ was considered significant. Categorical variables were compared with the $\mathrm{Chi}^{2}$ or the Fisher exact tests, each when appropriate, and the significance of differences was established by calculating the odds ratio with the $95 \%$ confidence interval.

The variables available in all patients and significantly different in the univariate analysis were included in a multivariate analysis based on a logistic regression model to identify if they were independently related to the risk of primary failure. To provide cutt-off points useful in clinical practice to predict the risk of suffering primary failure, ROC curves were plotted and the odds ratios (with $95 \%$ confidence interval) for the median values of each significant independent variable in the multivariate analysis were calculated.

Data were analyzed using statistical software SPSS version 17.0 (SPSS. Chicago, IL, USA) and EPIDAT statistical package (Xunta de Galicia, Spain).

\section{RESULTS}

Two hundred and fifty one patients (152 males) met the inclusion criteria. One hundred and forty one achieved a sustained viral response. In 110 patients the therapy was stopped due to primary viral failure, 58 in application of the 12 weeks stopping rule and 52 due to detectable viral load at week 24 of therapy. From the remaining 125 patients, 70 relapsed after transient viral response and 55 interrupted the therapy due to severe adverse events (intolerance).

Table I summarizes the demographic, analytical, virological and histological data of the two study groups. All patients were white (240 Spaniards), except one Chinese woman. In the univariate analysis, age, platelet count, AST/ALT ratio, GGT, serum cholesterol, viral subtype (1b vs. 1 non b), low $(\leq 400,000 \mathrm{IU} / \mathrm{mL})$ vs. high (> 400,000 IU mL) viral load, according to Witthöft et al. (5), and body mass index adjusted ribavirin dose were significantly different between SVR and therapy primary failure groups. From these, only age, GGT, serum cholesterol and low vs. high viral load were identified as inde- 
Table I. Baseline characteristics included in the search of predictive criteria of primary failure of therapy ${ }^{1}$

\begin{tabular}{|c|c|c|c|c|}
\hline \multirow[t]{2}{*}{ Baseline characteristics } & \multirow{2}{*}{$\begin{array}{c}\text { SVR } \\
\text { (141 cases) }\end{array}$} & \multirow{2}{*}{$\begin{array}{l}\text { Primary failure } \\
\text { (110 cases) }\end{array}$} & \multicolumn{2}{|c|}{ Statistical analysis } \\
\hline & & & Univariate & Multivariate \\
\hline Gender (M/F) & $87 / 54$ & $65 / 45$ & $\mathrm{OR}=0.89(95 \% \mathrm{Cl} 0.54-1.49)$ & \\
\hline Age (yrs.) & $45.5(10.8)$ & $50.4(10.2)$ & $<0.001$ & 0.002 \\
\hline$\left.B M\right|^{2}$ & $25.32(3.62)$ & $25.74(3.38)$ & 0.334 & \\
\hline PEG- $\alpha-\operatorname{IFN}(2 \mathrm{~b} / 2 \mathrm{a})$ & $103 / 38$ & $88 / 22$ & $\mathrm{OR}=1.48 .95 \% \mathrm{Cl} 0.81-2.68$ & \\
\hline RBV dose (mg/day)/BMI ${ }^{2}$ & $40.0(5.2)$ & $38.5(4.5)$ & 0.024 & 0.096 \\
\hline $\mathrm{Hb}(\mathrm{g} / \mathrm{dL})$ & $15.0(1.2)$ & $15.2(1.2)$ & 0.281 & \\
\hline Leucocytes ( $\mu \mathrm{L})$ & $6496(1726)$ & $6527(1999)$ & 0.897 & \\
\hline Neutrophils ( $\mu \mathrm{L})$ & $3461(1266)$ & $3396(15,41)$ & 0.570 & \\
\hline Platelets (10\% $/ \mathrm{L})$ & $218(63)$ & $192(58)$ & $<0.001$ & 0.094 \\
\hline Bilirubin (mg/dL) & $0.86(0.37)$ & $0.95(0.49)$ & 0.059 & \\
\hline AST (IU) & $69(52)$ & $81(69)$ & 0.08 & \\
\hline ALT (IU) & $116(89)$ & $114(93)$ & 0.502 & \\
\hline AST/ALT & $0.65(0.25)$ & $0.76(0.27)$ & $<0.001$ & 0.193 \\
\hline GGT (IU) & $62(64)$ & $134(172)$ & $<0.001$ & $<0.001$ \\
\hline Cholesterol (mg/dL) & $189(37)$ & $165(34)$ & $<0.001$ & $<0.001$ \\
\hline Viral subtype (1b/1 non b) & $97 / 44$ & $89 / 21$ & $O R=1.92 .95 \% \mathrm{Cl} 1.06-3.48$ & 0.491 \\
\hline Viral load $(\leq 400,000 \mathrm{IU} / \mathrm{mL} \geq 400,000 \mathrm{IU} / \mathrm{mL})$ & $37 / 104$ & $6 / 104$ & $\mathrm{OR}=6.17 .95 \% \mathrm{Cl} 2.50-15.23$ & $<0.001$ \\
\hline Uric acid (mg/dL) (185 patients) & $5.41(1.41)$ & $5.59(1.32)$ & 0.383 & Not included \\
\hline Advanced fibrosis (no/yes) (176 patients) & $62 / 38$ & $33 / 43$ & $\mathrm{OR}=2.13 .95 \% \mathrm{Cl} 1.16-3.90$ & Not included \\
\hline
\end{tabular}

${ }^{1}$ Continuous variables are expressed as mean (SD); ${ }^{2}$ BMI: body mass index.

Table II. AUROC (for continuous variables) and odd ratios for the identified independent variables at specific cut-off values

\begin{tabular}{lcccc}
\hline Variable & AUROC (95\% C.I.) & Cut-off value & Odds ratio (95\% CI) & p value (Chi test) \\
\hline Age (yrs) & $0.631(0.561-0.700)$ & $>47 \mathrm{yrs}$. & $1.79(1.08-2.96)$ & 0.023 \\
\hline GGT (IU/mL) & $0.749(0.689-0.806)$ & $>60 \mathrm{IU} / \mathrm{mL}$ & $4.25(2.49-7.24)$ & $<0.001$ \\
\hline 1/Cholesterol (mg/dL) & $0.678(0.612-0.745)$ & $<178 \mathrm{mg} / \mathrm{dL}$ & $2.93(1.75-4.92)$ & $<0.001$ \\
\hline Low vs. high viral load & & $>400,000 \mathrm{UI} / \mathrm{mL}$ & $6.17(2.50-15.23)$ & $<0.001$ \\
\hline
\end{tabular}

pendent variables related to the risk of suffering from primary therapeutic failure. Table II summarizes the individual AUROC values for each continuous independent variable and the odds ratios for their respective median values (with the addition of viral load, the only significant categorical variable, which cut-off value is 400,000 $\mathrm{IU} / \mathrm{mL}$ ) to discriminate between SVR and primary failure groups.

Forty six $(79.3 \%)$ of the 58 patients with all three unfavorable values for viral load, GGT and cholesterol were primary non-responders, whereas 11 (92\%) of the 12 patients with the three favorable values obtained SVR. However, these 70 patients with extreme values only represent $29 \%$ of the whole series. Basal plasma uric acid levels were available in 185 patients (Table I), without significant differences between the 102 who achieved SVR and the 83 primary non-responders (Table I). The cut-off point for serum uric acid $\geq 5.8$ proposed by Pellicano et al. (16) had no predictive role of response in our study, as SVR was obtained by
$56.7 \%$ and $53.1 \%$ of patients under and over the cut off value, respectively.

Results of a liver biopsy were available in 176 patients. There was a significant excess of patients with advanced fibrosis in the group of primary therapeutic failure (56.6 vs. 38.0\%, OR = 2.13. 95\% CI 1.16-3.90). Cirrhosis was diagnosed in 16 cases, eight in each group of response.

\section{DISCUSSION}

Contrarily to many previous studies, the main objective of this study was to elucidate which factors are related to the risk of primary therapeutic failure instead of which ones define the probability of reaching SVR. Our purpose was to eliminate the heterogeneity of a comparison group composed of three categories of disappointing end-points of therapy: primary failure, relapse and intolerance, each depending on different causes and mechanisms. 
Previous reports indicated that older age is a negative predictor of SVR in chronic hepatitis C genotype 1 (1720 ), with only one contradictory study (21). From "the other side of the mirror", our study confirmed that older age increases the risk of primary failure. Age directly correlates with the duration of the infection, although in many cases the date and mechanism of infection are unknown, a fact that justifies the relatively poor statistical power of this factor. We also confirmed previous reports signaling that a low viral load is the strongest predictor of SVR when the comparison is made with patients who suffer primary failure; unfortunately, only a minority of genotype 1 patients are included in this category $(17,19,20,22,23)$. We used the limit of $400,000 \mathrm{IU} / \mathrm{mL}$ proposed by Witthöft et al. (5) as the best discriminant one between low and high viral rate, but results would not have changed if higher limits $(600,000$ or 800,000 $\mathrm{IU} / \mathrm{mL}$ ) had been used instead.

Craxi et al. (21) found that genotype 1a improves the chance of SVR, and our univariate analysis was in agreement with this finding, but its significance disappeared in the multivariate analysis, because this factor is closely related to age (data not shown). A low platelet count, a well known surrogate marker of advanced liver fibrosis (24) is another criterion that heralds primary failure, but in this study it did not reach statistical significance, probably due to the low proportion of patients with liver cirrhosis. Together with a high viral load, GGT and plasma cholesterol levels were the factors most strongly associated to the risk of primary failure in our study. GGT has been identified as a prognostic factor in other studies $(17,23)$ and it is also a surrogate marker of liver fibrosis, as corroborates its inclusion in non-invasive scoring systems aimed to evaluate the stage of fibrosis (25). Moreover, GGT levels are related with an increased expression of $\mathrm{TNF} \alpha$ in the liver that seems to reduce the efficacy of antiviral therapy (26). Low serum cholesterol levels have been unanimously identified as a negative predictor of therapeutic success $(20,27,28)$, and they seem to be a consequence of specific defects in lipoprotein metabolism that cause low levels of LDL (28-31), but it is not clear how this may be related to the efficacy of antiviral therapy. Recently, Angelico et al. (32) have shown in a prospective analysis that included 65 patients (37 genotype 1) that low plasma cholesterol is associated with failure in achieving rapid virological response, defined as undetectable HCV RNA at week 4 of therapy.

This was a retrospective study. This drawback explains why we can not discuss the role of insulin resistance, which seems very important in determining the failure of antiviral therapy $(22,33)$. However, our results did not confirm the suggested relation between the chance of SVR and basal values for serum uric acid (16) and neutrophil count $(34,35)$.

We conclude that primary therapeutic failure may be predicted quite accurately in a low proportion of patients carrying an unfavorable combination of easily available basal criteria. Although many patients show an intermediate profile, our findings may help to establish the indication of antiviral therapy in patients with extreme values for these criteria.

\section{REFERENCES}

1. Manns MP, McHutchison JG, Gordon SG, Rustgi VK, Shiffman M, Reindollar R, et al. Peginterferon alfa-2b plus ribavirin compared with interferon alfa-2b plus ribavirin for initial treatment of chronic hepatitis C: a randomised trial. Lancet 2001; 358: 958-65.

2. Fried M, Shiffman M, Reddy R, Smith C, Marinos G, Goncales F, et al. Peginterferon 2a plus ribavirin for chronic hepatitis $C$ virus infection. N Engl J Med 2002; 347: 975-82.

3. Hadziyannis SJ, Sette H, Morgan TR, Balan V, Diago M, Macellin P, et al. Peginterferon alpha $2 \mathrm{a}$ and ribavirin combination therapy in chronic hepatitis $\mathrm{C}$ : a randomized study of treatment duration and ribavirin dose. Ann Intern Med 2004; 140: 346-55.

4. Lee SS, Bain VG, Peltelkian K, Kradjens M, Yoshida EM, Deschenes $\mathrm{M}$, et al. Treating chronic hepatitis $\mathrm{C}$ with pegylated interferon alfa-2a (40 KD) and ribavirin in clinical practice. Aliment Pharmacol Ther 2006; 23: 397-408.

5. Witthöft Th, Möller B, Wiedmann KH, Mauss St, Link R, Lohmeyer $\mathrm{J}$, et al. Safety, tolerability and efficacy of peginterferon lpha-2a and ribavirin in chronic hepatitis $\mathrm{C}$ in clinical practice: The German Open Safety Trial. J Viral Hepatitis 2007; 14: 788-96.

6. Fontanges T, Beorchia S, Douvin C, Delassalle P, Combis J-M, Hanslik B, et al. Safety and efficacy of combination therapy with peginterferon alfa-2a $(40 \mathrm{kD})$ and ribavirin in the outpatients setting: prospective analysis of 197 patients with chronic hepatitis C viral infection. Gastroenterol Clin Biol 2007; 31: 566-72.

7. Borroni G, Andreotti M, Casiraghi MA, Ceriani R, Guerzoni P, Omazzi B, et al. Effectiveness of pegylated interferon/ribavirin combination in "real world" patients with chronic hepatitis $\mathrm{C}(\mathrm{HCV})$ infection. Aliment Pharmacol Ther 2008; 27: 790-7.

8. Ladero JM, López-Alonso G, Devesa MJ, Cuenca F, Agreda M, Ortega L, et al. The " 12 weeks stopping rule" in the treatment of genotype 1 chronic hepatitis C: Two prognostic categories under the same label? Scand J Gastroenterol 2008; 43: 979-83.

9. Berg T, Von Wagner M, Nasser S, Sarrazin C, Heintges T, Gerlach $\mathrm{T}$, et al. Extended treatment duration for hepatitis $\mathrm{C}$ virus type 1: comparing 48 versus 72 weeks of peginterferon-alfa-2a plus ribavirin. Gastroenterology 2006; 130: 1086-97.

10. Pearlman BL, Ehleben C, Saifee S. Treatment extension to 72 weeks of peginterferon and ribavirin in hepatitis $\mathrm{C}$ genotype 1-infected slow responders. Hepatology 2007; 46: 1688-94.

11. Jensen DM. Individualizing HCV treatment with peginterferon and ribavirin: what needs to be done? Ther Adv Gastroenterol 2009; 2: 510 .

12. Bruguera M, Bañares R, Córdoba J, Jardí R, González-Lahoz J, Ladero JM, et al. Documento de consenso de la AEEH sobre el tratamiento de las infecciones por los virus de las hepatitis B y C. Gastroenterol Hepatol 2006; 29 (Supl. 2): 216-30.

13. Ghany MG, Strader DB, Thomas DL, Seeff LB. Diagnosis, management, and treatment of hepatitis C: an update. Hepatology 2009; 45: 1335-74.

14. Heid CA, Stevens J, Livak KJ, Williams PM. Real time quantitative PCR. Genome Research 1996; 6: 989-94.

15. Knodell RG, Isaac KG, Black WC, Chen TS, Craig R, Kaplowitz N, et al. Formulation and application of a numerical scoring system for assessing histological activity in asymptomatic chronic active hepatitis. Hepatology 1981; 1: 431-5.

16. Pellicano R, Puglisi G, Ciancio A, Balzola F, Saracco G, Ciccone G, et al. Is serum uric acid a predictive factor of response to IFN-treatment in patients with chronic hepatitis C infection? J Med Virol 2008; 80: 628-31.

17. Mihm U, Herrmann E, Sarrazin C, Zeuzem S. Peredicting response in hepatitis C virus therapy. Aliment Pharmacol Ther 2006; 23: 1043-54.

18. Iwasaki Y, Ikeda H, Araki Y, Osawa T, Kita K, Ando M, et al. Limi- 
tation of combination therapy of interferon and ribavirin for older patients with chronic hepatitis C. Hepatology 2006; 43: 54-63.

19. Foster GR, Fried MW, Hadziyannis SJ, Mesiger D, Freivogel K, Weiland O. Prediction of sustained virological response in chronic hepatitis $C$ patients treated with peginterferon alfa-2a (40KD) and rivavirin. Scand J Gastroenterol 2007; 42: 247-55.

20. Mauss S, Hueppe D, Zehnter E, Richter S, Tappe A, Herrmann E. Evaluation of a predictive model of individual chance for sustained virological response in patients with chronic hepatitis $\mathrm{C}$ treated with peginterferon alfa-2a and ribavirin. J Hepatol 2009; 50 (Supl. 1): S233 (abstract).

21. Craxi A, Piccinino F, Alberti A, Ascione A, Rizzetto M, Iannacone $\mathrm{C}$, et al. Predictors of SVR in naive HCV G1 patients in real life practice: the probe. J Hepatol 2008; 48 (Supl. 2): S291 (abstract).

22. Dai CY, Huang JF, Hsieh MY, Hou NJ, Lin ZY, Chen CS, et al. Insulin resistance predicts response to peginterferon-alpha/ribavirin combination therapy in chronic hepatitis C patients. J Hepatol 2009; 50: $712-8$.

23. Hernández A, Domper F, León A, Lorente R, López B, de la Santa E, et al. Viral kinetics during the first month of treatment in patients with genotype 1 chronic hepatitis C. Rev Esp Enferm Dig 2009; 101: 671-9.

24. Ladero JM, Delkader J, Ortega L, Fernández C, Devesa MJ, LópezAlonso G, et al. Non-invasive evaluation of the fibrosis stage in chronic hepatitis C: A comparative analysis of 9 scoring methods. Scand J Gastroenterol 2010; 45: 51-9.

25. Forns X, Ampurdanes S, Llovet JM, Aponthe J, Quinto L, MartinezBauer $\mathrm{E}$, et al. Identification of chronic hepatitis $\mathrm{C}$ patients without hepatic fibrosis by a simple predictive model. Hepatology 2002; 36: 986-92.

26. Taliani G, Badolato MC, Nigro G, Biasin M, Boddi V, Pasquazzi C, et al. Serum concentration of $\gamma \mathrm{GT}$ is a surrogate marker of hepatic TNF- $\alpha$ mRNA expression in chronic hepatitis C. Clin Immunol 2002; 105: 279-85.

27. Backus LI, Boothroyd DB, Phillips BR, Mole LA. Predictors of response of U.S. veterans to treatment for the hepatitis C virus. Hepatology 2007; 46: 37-47.
28. Economou M, Milionis H, Filis S, Baltaviannis G, Christou L, Alisaf $\mathrm{M}$, et al. Baseline cholesterol is associated with the response to antiviral therapy in chronic hepatitis C. J Gastroenterol Hepatol 2007; 23: 586-91.

29. Akuta N, Suzuki F, Kawamura Y, Yatsuji H, Sezaki H, Suzuki H, et al. Predictive factors of early and sustained responses to peginterferon plus ribavirin combination therapy in Japanese patients infected with hepatitis $\mathrm{C}$ virus genotype $1 \mathrm{~b}$ : aminoacid substitutions in the core region and low-density lipoprotein cholesterol levels. J Hepatol 2007; 46: 403-10.

30. Sheridan DA, Price DA, Schmid M, Toms GL, Donaldson P, Neely $\mathrm{D}$, et al. Apolipoprotein $\mathrm{B}$ associated cholesterol is a determinant of treatment outcome in patients with chronic hepatitis $\mathrm{C}$ virus (HCV) infection receiving anti-viral agents interferon-alpha and ribavirin. Aliment Pharmacol Ther 2009; 29: 1282-90.

31. Mawatari H, Yoneda M, Fujita K, Nozaki Y, Shinonara Y, Sasaki H, et al. Association between lipoprotein subfraction and the response to hepatitis C treatment in Japanese patients with genotype 1b. J Viral Hepatitis 2009 (epub ahead of print)

32. Angelico F, Francioso S, Del Ben M, Feole K, Carbone M, Pignatelli $\mathrm{P}$, et al. Low plasma cholesterol and oxidative stress predict rapid virological response to standard therapy with peginterferon and ribavirin in HCV patients. Aliment Pharmacol Ther 2009; 30: 444-51.

33. Romero-Gómez M, Viloria MM, Andrade RJ, Salmerón J, Diago M, Fernández-Rodríguez CM, et al. Insulin resistance impairs sustained response rate to peginterferon plus ribavirin in chronic hepatitis $\mathrm{C}$ patients. Gastroenterology 2005; 128: 636-41.

34. Shirakawa H, Matsumoto A, Joshita S, Komatsu M, Tanaka N, Umemura T, et al. Pretreatment prediction of virological response to peginterferon plus ribavirin therapy in chronic hepatitis C patients using viral and host factors. Hepatology 2008; 48: 1753-60.

35. Álvarez-Uria G, Day JN, Nasir AJ, Russell SK, Vilar FJ. Reduction in neutrophil count during hepatitis $C$ treatment: drug toxicity or predictor of good response? Dig Dis Sci 2009 Sep 16 [Epub ahead of print]. 